UDK: 316.647.6:82-95:001.891"1936/..."

Izvorni naučni rad

Primljeno: 30. 9. 2019.

Prihvaćeno za štampu: 13. 1. 2020.

mr. sci. Dijana Sulejmanović, viši asistent

Univerzitet u Bihaću

Islamski pedagoški fakultet

E-mail:dijana.sulejmanovi@@unbi.ba

\title{
PREGLED DOSADAŠNJIH ISTRAŽIVANJA KONFORMIZMA: "KAD SI U RIMU, PONAŠAJ SE KAO RIMLJANIN"
}

\section{Sažetak}

Kao rezultat socijalnog utjecaja, fenomen konformizma se može pojaviti u malim grupama, ali $i$ u citavom drusttvu kao čin uporedivanja stavova, uvjerenja i ponašanja s normama grupe. Premda samo postojanje društva podrazumijeva postojanje određenog stepena konformizma u vidu popuštanja zahtjevima većine, praćenja trendova $i$ zajedničkih aktivnosti u svrhu napretka čovječanstva, fenomen konformizma istraživački je zanimljiv obično u slućajevima kada podrazumijeva odstupanje pojedinca od vlastitih vrijednosti, stavova, mišljenja i procjena kako bi se priklonio većini, bilo radi toga što sam nije siguran u ispravnost svoje procjene ili pak ne želi ugroziti svoj položaj u određenoj socijalnoj grupi.

Ne postoji jedno, općeprihvaćeno, objašnjenje konformizma. Jedni autori ga odrectuju kao svako usvajanje grupnih normi, a drugi kao mijenjanje ponašanja uslijed zamišljenog ili stvarnog pritiska grupe. No, mijenjaju li pojedinci svoje mišljenje pod uticajem socijalne sredine ili pak odustaju od vlastitih stavova samo izvana, a privatno zadržavaju svoja uvjerenja? Kakve nedostatke imaju dosadašnja istraživanja konformizma i kako je konformizan ispitivan na nasim prostorima i u svijetu, problem je kojim se bavimo u ovom radu. Cilj rada je prikazati historijat $i$ razvoj istraživanja konformizma, od pionirskih radova Sherifa i Ascha do danas, pritom (prateci) dobivene rezultate smjestiti $u$ historijski i društveni okvir.

Ključne riječi: konformizam, socijalni utjecaj, normativni socijalni utjecaj, informacijski socijalni utjecaj. 


\section{Uvod}

Socijalni utjecaj, šire određeno, pojam je iz područja socijalne psihologije koji se odnosi na utjecaj socijalnih faktora na ponašanje, dok uže određeno, označava promjenu u kognitivnim aktivnostima stavovima, mišljenju i procjenama te ponašanju i emocijama nekog pojedinca, a koja je nastala kao rezultat njegove izloženosti stavovima, mišljenju i procjenama drugih (Hewstone i Stroebe, 2003), odnosno, kao posljedica odnosa pojedinca i drugih - pojedinaca, grupa ili društva (Abrams \& Hogg, 1990). No, mijenjaju li pojedinci svoje mišljenje pod utjecajem socijalne sredine ili pak odustaju od vlastitih stavova samo izvana, a privatno zadržavaju svoja uvjerenja? Pod kojim uslovima se pojedinci uspijevaju oduprijeti utjecaju većine, a pod kojim većina utiče na promjenu nečijeg mišljenja?

Jedan od oblika socijalnog utjecaja je svakako i konformizam fenomen koji se može pojaviti u malim grupama, ali i u čitavom društvu kao rezultat utjecaja drugih i pritisaka grupe, a kao čin upoređivanja stavova, uvjerenja i ponašanja s normama grupe (Cialdini i Goldstein, 2004).

Popuštanje nečijim zahtjevima, ističe Pennington (1997), čak i kada ti zahtjevi ne sadržavaju naređenje ili zapovijest, dio su naše svakodnevnice.

Najstariji poznat eksperiment o socijalnom utjecaju djelo je Muzafera Sherifa (1936.) koji je pokazao da pojedinac, ne samo da se prilagođava većini, nego nastavlja koristiti grupni referentni okvir kao svoj i onda kada izvor utjecaja, tj. grupa, prestane biti prisutna. Sherifov rad se može smatrati prapočetkom istraživačkog pristupa fenomenu konformizma.

Solomon Asch je 1950. godine započeo niz eksperimentalnih istraživanja kakav je to socijalni pritisak većinske grupe koji može da utiče na pojedinca i izazove te na njegovo konformističko prepuštanje (1956). Aschov postupak ili tzv. Aschova paradigma je tehnika laboratorijskog mjerenja konformističkog ponašanja koja omogućava da se pojedinac stavi pod socijalni pritisak koji se može kontrolisati i kojim je moguće sistematski manipulirati. Aschov eksperiment je prvi u nizu kultnih psiholoških eksperimenata koji su osmišljavani s ciljem razumijevanja i objašnjavanja tragičnih stradanja ljudi tokom II 
svjetskog rata. Njegovi nalazi o konformiranju i kasnije Milgramove potvrde ljudske poslušnosti, odnosno pokornosti autoritetu, dali su djelimično odgovor na pitanje kojim su rezultirali brojni surovi zločini čovjeka nad čovjekom, sredinom prošlog vijeka - kako su mogli?

Gdje je i koliko je jasna granica kada dvije glave (ni)su pametnije od jedne, problem je kojim se bavimo u ovom radu. Cilj nam je prikazati historijat istraživanja konformizma, od Sherifa i Ascha do danas, kao i pratiti dobivene rezultate smještajući ih u historijski i društveni okvir.

\section{Teorijski pristupi pojmu konformizma}

Kako definisati konformizam - centralni pojam ovog rada? Konformizam je promjena ponašanja ili uvjerenja prema grupi kao posljedica stvarnog ili zamišljenog pritiska grupe (Keisler \& Keisler, 1972, prema Pennington, 1997) i podrazumijeva da:

1) promjena prema grupi je ona koju grupa prihvata i odobrava,

2) konformiranje prema očekivanjima i normama grupe može da bude devijantno prema drugoj grupi.

O adekvatnosti ovakvih određenja konformizma bi se dalo diskutovati, a u nastavku ćemo prikazati historijat određivanja značenja samog pojma "konformizam".

Pomenuta objašnjenja bliže određuju Deutsch i Gerard (1955, prema Carpenter, 2004) koji konformizam kao fenomen objašnjavaju jednim od dva moguća razloga. Prvi razlog je rezultat potrebe za uklapanjem, odnosno potreba za prihvatanjem od strane drugih ili pak izbjegavanje sankcija zbog odstupanja od socijalnih normi, kao što je zaustavljanje na znaku "stop" u saobraćaju ili poštovanje tišine u biblioteci i to je tzv. normativni socijalni utjecaj. Drugi razlog nastaje iz potrebe za informacijama i to je tzv. informacijski socijalni utjecaj ili vjerovanje tačnosti informacija koje nude drugi. On je prisutan kada osoba ne zna šta treba da misli i kako da se ponaša u konkretnoj situaciji pa se oslanja na informacije drugih ljudi, vjerujući da je njihovo tumačenje tačnije. Inače, ovakva vrsta konformizma se primjećuje i kod nekih životinjskih vrsta, na primjer čimpanzi (van Schaik, 2012).

Indikator konformizma je svako popuštanje pritisku grupe. Naime, ljudi imaju prirodnu potrebu za evaluacijom svojih sposobnosti, uvjerenja i 
mišljenja u odnosu na druge pa, prema teoriji socijalne usporedbe, koriste okolinu kao referentnu tačku onda kada sumnjaju u sebe (Pennington, 1997), a kako bi dobili smjernice za poželjno i prihvatljivo ponašanje. Konformizam, također, može biti posljedica potrebe da se izbjegne sukob s drugima u situacijama kada se pojedinac ne slaže s većinom. Kako bi izbjegao neprijatnost i moguće posljedice poput neprihvatanja ili odbacivanja, pojedinac će se pokoriti većini, odnosno korformirati se.

Prema nešto novijem Rotovom određenju, konformizam predstavlja prihvatanje ponašanja grupe ili većine zato što grupa takvo ponašanje zahtijeva ili očekuje ili zato što ga prosto prezentuje kao način ponašanja (2003), odnosno, on pod pojmom konformizma podrazumijeva spremnost da se mišljenje drugih osoba i grupa kojima pojedinac pripada prihvati i kada za takvo prihvatanje nema realnih i racionalnih razloga.

\section{Historijat istraživanja konformizma}

Historijski pregled istraživanja iz oblasti socijalne psihologije pokazuje kako su istraživanja socijalnog utjecaja bila među glavnim istraživačkim problemima u ovoj oblasti. S korijenima u radovima još Muzafera Sherifa, jednog od osnivača socijalne psihologije, 1936. godine i Solomona Ascha pedesetih godina prošlog stoljeća, konformizam je i danas oblast aktivnog istraživanja socijalnih psihologa. Snaga koju socijalni utjecaj može imati s jedne strane, i sklonost konformiranju pojedinca s druge strane, čine se kao uspješna formula za upravljanje masama u bilo kakve svrhe i za bilo kakva (ne)djela.

\section{Sherif i Asch - pionirska istraživanja konformizma}

Sherifov eksperiment primjer je informacijskog socijalnog utjecaja, dok Aschov rad predstavlja primjer normativnog socijalnog utjecaja.

Sherifov "Autokinetički eksperiment”. Prvi naučni eksperiment o konformizmu proveden je 1936. godine od strane Muzafera Sherifa, jednog od osnivača socijalne psihologije, a nazvan je Autokinetički eksperiment. Sherif je eksperiment utemeljio na iluziji kretanja nepomične tačke svjetla posmatrane u potpunom mraku, tzv. 
autokinetičkom efektu, do kojeg dolazi kada ne postoji stabilna uporišna tačka da bi se mogla usidriti pozicija svjetla.

Ispitanici su sjedili sami u mračnoj sobi te im je rečeno da gledaju u malu tačku svjetlosti koja je bila udaljena otprilike 4.5 metara. Nakon toga je od ispitanika zatraženo da daju procjenu koliko daleko se svjetlo pomjera. Tačka se, naravno, uopšte nije pomjerila, ali su ispitanici tokom 100 pokušaja postigli vlastitu stabilnu procjenu koja se razlikovala od osobe do osobe i to od $2.5 \mathrm{~cm}$ do $25 \mathrm{~cm}$. Nekoliko dana kasnije, ispitanici su trebali ponovo dati svoju procjenu o kretanju tačke svjetla, ali ovog puta su bili u istoj prostoriji $\mathrm{s}$ još dvoje ili troje ispitanika, a odgovore su davali usmeno i nakon njih.

Dobiveni podaci pokazali su da pojedinci veličinu tog pomjeranja procjenjuju sasvim različito - zavisno od toga da li su sami, ili su $u$ grupi drugih procjenjivača. Naime, kada su odgovarali grupno, ispitanici su davali procjenu sličniju procjenama ostalih ispitanika nego kada su odgovarali samostalno. Onima s prvobitnim utiskom da se radi o malim oscilacijama, učinile su se te oscilacije većim nakon što su ih drugi proglasili takvima. I suprotno - oni koji su pomjeranja samostalno procjenjivali kao veća, svoje procjene su korigovali, tj. smanjili su procijenjenu udaljenost nakon procjena ostalih učesnika eksperimenta. Sherif je ovim eksperimentom otkrio fenomen utjecaja grupe na individualnu procjenu veličine tog pomjeranja, odnosno tendenciju da se, iako prethodno različite, procjene članova grupe, nakon što su čuli jedni druge, uzajamno približavaju. Ovakvo ponašanje primjer je, podsjećamo, tzv. informacijskog socijalnog utjecaja, odnosno pojave da u situacijama koje se procjenjuju kao nedovoljno jasne, posmatramo druge ljude i njihovo ponašanje kako bismo dobili tačnu informaciju.

Asch $i$ "Aschova paradigma". Asch je 1950. godine u Pensilvaniji, na Swarthmore koledžu izveo, sada već klasičan, eksperiment, a zanimalo ga je da li će se ljudi konformirati u situaciji u kojoj su procjene grupe očigledno pogrešne (Asch, 1956).

Eksperiment je obuhvatio ukupno 123 ispitanika, koji su nazvani "kritičkim subjektom." Ispitanici su bili muškarci uzrasta od 17 do 25 godina, u prosjeku 'stari' 20 godina. Eksperiment je sproveden u tri kvalitativno različite institucije. Prvu, privatnu, školu su pohađali srednjoškolci čiji su roditelji bili visoko obrazovani i ekonomski dobro 
situirani. Druga je bila javna srednja škola koju su pohađali pripadnici donjeg sloja srednje klase. Roditelji ovih učenika bili su naturalizovani doseljenici. Treća institucija bila je fakultet čiji studenti su edukacijski, intelektualno i materijalno bili inferiorniji u poređenju s prve dvije grupe. Napomenimo da su kritički subjekt i većinska grupa, iako su njeni članovi bili nepoznati subjektu, uvijek odabirani iz iste populacije.

Svaka grupa sadržavala je između 7 i 9 ispitanika, a kritički subjekt bio je u poziciji da bude manjina nasuprot nepoznate mu većine koja daje netačne, pogrešne odgovore. Naime, članovima grupe je prikazano 18 nizova linija, a njihov zadatak bio je da imenuju koja od linija s desne strane na ekranu - A, B ili C - je identična liniji prikazanoj na lijevoj strani.

Iako je tačan odgovor uvijek bio očigledan, saradnici su u 12 slučajeva davali pogrešan odgovor, a eksperimentator je bilježio koliko će kritičkih subjekata više "vjerovati tuđim očima, nego svojim", odnosno konformirati se s većinom i dati, također, pogrešan odgovor. Odgovore koje će zastupati grupa pred naivnim pojedincem - birao je sam Asch. On bi, "kao tačan", izabrao odgovor koji se upadljivo razlikovao od objektivno tačnog odgovora.

U svim serijama ispitanik je sjedio pretposljednji i odgovarao je pretposljednji. Asch je tokom godina izvršio više varijacija ovog eksperimenta, mijenjajući određene detalje poput nivoa obrazovanja i spola, a u potrazi za što boljim objašnjenjem konformizma kao fenomena reagovanja pojedinca na izloženost socijalnom uticaju.

Zaključno, Asch je došao do nalaza da skoro 37\% ispitanika pokazuje konformizam (Hewstone \& Stroebe, 2003), odnosno daju netačne odgovore kada to isto čine i drugi članovi. tj. većina. Tek $25 \%$ ispitanika $\mathrm{u}$ eksperimentalnoj grupi nije napravilo nijednu grešku, u poređenju s 95\% ispitanika u kontrolnoj grupi, odnosno onima koji nisu bili u situaciji da odgovaraju pod utjecajem drugih. Očekivano, kada su po završetku eksperimenta učesnici intervjuisani o razlozima svog konformiranja s većinom, mnogi od njih su priznali kako su davali netačne odgovore potpuno svjesno, plašeći se da će biti ismijani od strane grupe ako se suprotstave. Njihovi odgovori o razlozima konformiranja mogu se sažeti u tri kategorije - iskrivljenost percpecije, iskrivljenost suđenja (oni koji su vidjeli drugačije, ali su vjerovali da je 
većina, tj. grupa u pravu) te iskrivljenost akcije (oni koji su bili čvrsto uvjereni u tačnost svoje procjene, ali se nisu željeli razlikovati od većine).

Aschovom eksperimentu danas se može prigovoriti da je bio tek pokazatelj američke kulture 1950-ih godina te da zadaci koje je koristio nisu mogli izgledati realistično učesnicima eksperimenta.

Aschov eksperiment je primjer tzv. normativnog socijalnog utjecaja. Ovakvo konformiranje često je motivisano željom da se pojedinac svidi drugima i da bude ravnopravno prihvaćen kao član neke socijalne grupe pa se konformira socijalnim normama, odnosno nepisanim pravilima ponašanja koja vrijede u određenoj grupi. "Moderniji" primjer normativnog socijalnog utjecaja je ponašanje na socijalnim mrežama korisnici interneta izrađuju profile na mrežama koje su trenutno najpopularnije pa te profile dalje prilagođavaju profilima drugih korisnika, kao što je, naprimjer, pravljenje tzv. selfie fotografija za Facebook, fotografisanje hrane za Instagram, citiranje za Twitter, objavljivanje poslovnih rezultata i uspjeha na LinkedIn-u i slično.

\section{Od Sherifa i Ascha do danas}

Konformizam je srž najčuvenijih eksperimenata socijalnih psihologa, a u nastavku će biti prikazane replikacije i modifikacije klasičnih, pionirskih eksperimenata konformizma - kako u svijetu, tako i na našim prostorima.

Schachter, 1951. U svom eksperimentu o konformizmu, Schachter (1951) formira grupe od 5 do 7 studenata ekonomije koji su primljeni u klub i učestvuju u diskusiji na temu "Johnny Rocco - šta uraditi s ovim maloljetnim delinkventom - više ljubavi ili više kazne?" Saradnik eksperimentatora igrao je jednu od tri uloge pa se u prvom scenariju slagao s mišljenjem većine, u drugom se razlikovao, a zatim slagao, a u trećem scenariju se sve vrijeme razlikovalo njegovo mišljenje od mišljenja većine. Dobiveni rezultati su pokazali da je većina najčešće odbacila "neistomišljenika", odnosno da su prema njemu ostali članovi imali negativne izbore te su svi članovi grupe smanjivali komunikaciju s njim sve do potpunog prestanka, što je veći stepen konformizma nego što je dobiven u Aschovim istraživanjima Ovaj eksperiment jedan je od prvih pokušaja pristupa konformizmu kao mogućem pozitivnom socijalnom fenomenu. 
Milgram, 1961. Ashov asistent Stanley Milgram (1961) je istraživao osnovanost stereotipa koji postoje o pripadnicima određenih nacija. On je u nizu eksperimenata usporedio po 20 francuskih i norveških studenata, ispitujući da li je i konformizam više karakterističan za jedno društvo nego za drugo. Studenti su imali zadatak da odrede trajanja zvučnih signala, a tokom pet varijacija eksperimenta, norveški studenti su pokazali veći konformizam u odnosu na francuske studente (Slika 3), bilo da su odgovarali u standardnoj proceduri (62\%: 50\%) ili pismeno $(50 \%: 34 \%)$, a također su rjeđe tražili da ponove zadatak $(25 \%$ : $70 \%)$.

Milgram je kao zaključak naveo da postoje međunacionalne razlike $\mathrm{u}$ konformizmu kao socijalnom ponašanju, a njegovi nalazi također pokazuju na veći konformizam nego što je Solomon Asch dobio u svom eksperimentu.

Ovo Milgramovo istraživanje kasnije će postati temeljem za ispitivanje čovjekove poslušnosti autoritetu, eksperimenta koji se danas smatra jednim od najznačajnija tri ostvarenja u historiji socijalne psihologije, pored Aschovog ispitivanja konformizma i Zimbardovog eksperimentisanja s uživljavanjem ljudi u socijalne uloge.

Moscovici i Zavalloni, 1969. Važno je spomenuti i istraživanje Moscovicija i Zavallonijeve (1969) koji su saradnicima, također, dali instrukciju da se ponašaju suprotno od većine. Eksperimenti Schachtera te Moscovicija i Zavallonijeve su usmjerila istraživanja konformizma $u$ smjeru značaja manjine. Naime, kroz historiju postoji mnogo primjera utjecaja manjine na svim nivoima društva, poput Martina Luthera Kinga, Adolfa Hitlera, Karla Marxa i drugih poznatih ljudi koji su utjecali na ponašanje i mišljenje drugih.

Zadatak saradnika u eksperimentu Moscovicija i Zavallonijeve bio je da na pitanje "Koje je boje naknadna slika?" daju suprotan odgovor onom koji je dala većina drugih članova grupe. Njihov eksperiment sa 140 muških učesnika srednjoškolskog uzrasta je pokazao da se utjecaj manjine zasniva na informacionom, a ne na normativnom utjecaju. Također, ovaj eksperiment je pokazao da, ako se želi postići utjecaj na većinu, veliki značaj ima konzistentnost i dosljednost manjine. Naime, $8 \%$ pravih ispitanika "vidi" zelenu boju ako saradnici boju prikazanu 
na dijapozitivu uvijek imenuju kao zelenu, u poređenju s $1 \% \mathrm{u}$ slučajevima kada manjina nije konzistentna i ne odgovara dosljedno.

Nalazi Moscovicija i Zavallonijeve ukazuju na smanjenje stope konformizma u poređenju s Aschovim nalazima, što je možda utjecalo na zainteresovanost psihologa za bavljenje fenomenom konformizma pa se ovakva istraživanja u kasnijim godinama ne izvode često, sve do devedesetih godina prošlog vijeka, kada ponovo raste istraživačka radoznalost za izučavanje konformizma.

Pomenuta istraživanja imala su značajnu, premda pionirsku, ulogu u istraživanju utjecaja manjina, drugog socijalno-psihološkog fenomena koji se odnosi na mogućnost da u socijalnoj grupi većina promijeni svoje stavove, mišljenje i/ili ponašanje, ali pod neočekivanim utjecajem manjine u istoj grupi. Naime, psiholozi su pretpostavljali kako je teško da manjina uopće ima ikakav utjecaj na većinu pa su skoro sva rana istraživanja socijalnog utjecaja bila usmjerena na način na koji većina utječe na manjinu.

Marjanović, 1995. primjenjuje klasičnu Aschovu metodu laboratorijskog mjerenja konformističkog ponašanja na uzorku od 80 učenika srednje škole, a u cilju utvrđivanja povezanosti konformističkog ponašanja sa spolnom pripadnosti. Uzorak je bio ujednačen prema spolu te su formirane četiri grupe, a u svakoj grupi je bilo po sedmero mladića, odnosno djevojaka. Pritom, šestero su uvijek bili saradnici eksperimentatora, a sedmi član grupe bio je "naivni ispitanik". Marjanović je dizajnirala eksperiment tako da u grupi I mladići vrše pritisak na djevojke, u grupi II mladići na mladiće, u grupi III djevojke na mladiće, a u grupi IV su djevojke vršile pritisak na djevojke. Od ukupno 560 kritičkih suđenja, ispitanici su popustili socijalnom utjecaju u 191 slučaju, odnosno u 34.11\% slučajeva. Ovi rezultati su u skladu s nalazima koje je dobio i sam Asch, iako je hipoteza o postojanju spolnih razlika koju je Marjanović postavila kao polaznu - odbačena. Međutim, iako se razlike u konformiranju s obzirom na spol nisu pojavile, zanimljiv je rezultat da se ispitanici najslabije konformiraju u situacijama kada djevojke vrše pritisak na mladiće, dok je najjači konformizam kada mladići vrše pritisak na druge mladiće. 
Jedna od razlika između klasičnog Aschovog eksperimenta i rada Marjanovićeve (1995) jeste korištenje različite tehnike za dobivanje posteksperimentalnih podataka - Asch je koristio intervju, a Marjanović upitnik zasnovan na modifikaciji pomenutog Aschovog intervjua.

Baron i saradnici, 1996. Baron i saradnici (1996) su se bavili ispitivanjem koliko važnost utječe na prisutnost konformizma, odnosno na davanje tačnih ili konformistički obojenih odgovora. Oni su koristili donekle izmijenjen Aschov zadatak koji je zahtijevao uživljavanje ispitanika, a tražilo se od studenata da prepoznaju osumnjičenog u liniji za prepoznavanje, prije čega im je pokazan dijapozitiv počinilaca, nakon čega su vidjeli dijapozitiv linije za prepoznavanje s četiri muškarca od kojih je jedan bio počinilac koji se traži. Prepoznavanje se vršilo u grupi u kojoj su bili i saradnici eksperimentatora. Dijapozitivi su prezentovani brzo, tek pola sekunde, a svi su odgovarali naglas. Oba saradnika eksperimentatora su odgovarali prije naivnog subjekta $i$ davali su isti pogrešan odgovor u svakom pokušaju. Jednoj grupi učesnika rečeno je da je zadatak vrlo važan i ponuđena im je novčana nagrada, dok je druga grupa dobila uputstvo kako zadatak nije posebno bitan i da se radi o jednoj pilot studiji. Baron, Vandello i Brunsman nalaze da su u 26 varijacija eksperimenta, ljudi manje skloni da se konformiraju kada je zadatak važan, a očigledno je da grupa griješi te zaključuju da je za normativni socijalni utjecaj važnost zadatka jedan od presudnih faktora.

Bond $i$ Smith, 1996. Četiri decenije nakon slavnog Aschovog eksperimenta, Bond i Smith s Univerziteta u Sussexu, Velika Britanija (1996) su izradili obimnu studiju o konformizmu. Njihov rad je rezultat pregleda literature iz psiholoških baza podataka o 133 studije iz 17 zemalja i to u periodu od 1952. do 1994. godine, čime je uključeno 4627 ispitanika. Neke od varijabli koje su zanimale Bonda i Smitha su zemlja i godina istraživanja, oblik eksperimentalne paradigme, veličina uzorka, odnosi između većine i ispitanika (da li se međusobno poznaju), vrsta stimulusa te broj ponavljanja eksprimenta.

Ovo pregledno istraživanje pokazuje dosljedno veću stopu konformizma u kolektivističkim društvima nego u individualističkim, a pomenuta kros-kulturalna studija ujedno je i kros-nacionalno poređenje, čiji cilj je bio i da nadomjesti metodološke probleme i pokaže da li konstrukt individualno - kolektivno predstavlja vrijednost 
koja može značajno objasniti postojeće razlike. Polazeći od Milgramovih nalaza da su norveški studenti pokazali veći konformizam od francuskih (1961), Bond i Smith izdvajaju studije u kojima je dobiveno da postoje društva u kojima je konformizam značajno viši poput Kine, Zimbabwea, Ghane i Fijia, dok je u Njemačkoj i Americi konformizam niži nego što je bio $u$ Ashovom originalnom eksperimentu. Ovo ih vodi do zaključka da je u kolektivističkim društvima konformizam veći nego u društvima gdje se više cijeni individualnost. U prilog pomenutom, govore i nalazi da je konformizam veći kada grupu čine osobe koje se međusobno poznaju i imaju razvijene prijateljske odnose, nego kada su to stranci (Wiliams \& Sogon, 1984, prema Bond \& Smith, 1996). U istraživačkom pristupu fenomenu konformizma, vidimo, potrebno je uključiti kulturalne varijable kao prediktore $\mathrm{i}$ ispitivati njihovu ulogu $\mathrm{u}$ procesima socijalnog utjecaja uopšte.

Santor et al, 2000. Istraživanje tima iz Kanade (Santor et al, 2000) izvršeno je pomoću kratkih skala vršnjačkog utjecaja, vršnjačkog konformizma i popularnosti na plaćenom uzorku 148 starijih dječaka $(\mathrm{N}=40)$ i djevojčica uzrasta od 11. do 12. razreda, odnosno od 16 do 18 godina. Korišteno je nekoliko grupa varijabli i to: vršnjački pritisak (uz popularnost, vršnjački koformizam i opći konformizam), dobrobit (uz samopoštovanje $\mathrm{i}$ disforiju) te rizična ponašanja (uz zloupotrebu supstanci i stavove prema spolnosti) i školski uspjeh. Vidimo da je ovdje konformizam ispitivan tek kao dio varijable vršnjački pritisak, a autori, baveći se prediktivnom ulogom konformizma, nalaze da vršnjački pritisak potiče konformizam, ali i socijalno nepoželjna i neprihvatljiva ponašanja - ponašanja koja nazivamo rizičnima, kao što su konzumiranje alkohola (posebno piva), cigareta i droga, kao i seksualno devijantna ponašanja i stavove (Teunissen et al, 2012).

Haun i Tomasello, 2011. Zanimljiv pristup konformizmu pokazuju Haun i Tomasello (2011) s Instituta za evolucijsku antropologiju u Engleskoj. Oni su se bavili istraživanjem ove pojave na najranijem uzrastu - vrtićkom, a uzorak u prvom eksperimentu je obuhvatio 24 grupe od po četvero djece starosti oko četiri godine $(\mathrm{N}=96)$. Djeca su imala zadatak sličan onome iz Aschovog eksperimenta, s razlikom što su Haun i Tomasello umjesto vertikalno postavljenih linija koristili sličice životinja i objekata, tražeći od ispitanika da naglas sličicu 
ponuđenu s lijeve strane povežu s jednom od tri različite sličice s desne strane (Slika 6), nakon što čuju netačne odgovore svojih poznanika. Zapravo su objekti na sličicama s desne strane bili različitih dužina, kao i u Aschovom eksperimentu.

U drugom eksperimentu Hauna i Tomasella (2011), ispitivano je 72 četverogodišnjaka, a jedina razlika u odnosu na prvi eksperiment bila je u tome što je jedna grupa djece tiho, odnosno bez glasa, pokazivala svoj odgovor, a druga grupa je trebala odgovarati javno i naglas. Ispitanici su bili raspoređeni u 18 grupa po četvero.

U ovom eksperimentu nije došlo do promjene uvjerenja, ali su djeca pokazivala, očekivano, javno slaganje s većinom. Oko tri četvrtine ispitanika se konformiralo $\mathrm{s}$ većinom barem jednom. Ovi podaci potvrđuju ranije navedene nalaze Wiliamsa i Sogona (1984, prema Bond \& Smith, 1996), odnosno u skladu su s rezultatima o sklonosti normativnom konformizmu kod odraslih, posebno kada je potrebno odgovor dati javno, a što je još jedan dokaz stabilnosti ovog socijalnog fenomena tokom godina.

Yafai, Verrier \& Reidy, 2014. Ispitivanje konformizma na dječijem uzrastu bilo je u fokusu zanimanja još jednog tima britanskih istraživača. Studija socijalnog konformizma kod poremećaja iz autističnog spektra (Yafai, Verrier \& Reidy, 2014) rezultirala je zaključkom da se djeca $\mathrm{s}$ autističnim poremećajima konformiraju manje, što pokazuje da je konformizam socijalni fenomen, a znajući da su poteškoće u socijalnom funkcionisanju jedno od osnovnih obilježja poremećaja iz autističnog spektra. Njihov rad zanimljiv je ne toliko zbog repliciranja Aschovog eksperimenta nego zbog razumijevanja konformizma kao sposobnosti kod djece s autizmom.

Egebark i Ekstrom, 2011. Raznolikost pristupa istraživanju konformizma dokazuje univerzalnost ove pojave u različitim društvima i vremenskim razdobljima. U Švedskoj su istraživači zanimljivim našli konformizam na društvenim mrežama. Egebark i Ekstrom (2011) postavili su 44 statusa, odnosno objava, tokom sedam mjeseci i koristeći se s pet Facebook naloga. Pratili su broj lajkova, tj. sviđanja od strane drugih korisnika $(\mathrm{N}=710)$, nakon što je neko već "lajkom podržao"određenu objavu, a varirala su tri uslova - jedan "lajk" nepoznate osobe, tri "lajka" nepoznatih osoba ili jedan "lajk" 
poznanika. Lajkovi su u ovom radu interpretirani kao izraz konformizma, odnosno podržavanje i ispoljavanje sličnih preferencija, a dobiveni rezultati navode na zaključak da će konformizam na društvenim mrežama biti veći kada je pojedinac okružen svojim poznanicima, odnosno da se ljudi prije konformišu s poznatim osobama. Svakako da bi se metodološkim rješenjima u ovom istraživanju moglo pronaći mnogo manjkavosti, prvenstveno zbog nedovoljno jasnog određivanja šta je konformizam, a šta stvarno sviđanje. Istraživački radovi na temu društvenih mreža rezultat su ekspanzije različitih internetskih servisa za online umrežavanje, bilo da je to $\mathrm{u}$ profesionalne (npr. LinkedIn) ili privatne svrhe (Facebook, Instagram, Twitter i drugi).

\section{Istraživanje konformizma kao vrijednosti}

Iako, u cilju opstanka, društvo usmjerava ljude da misle i djeluju na društveno prihvatljiv i društveno poželjan način, što nerijetko nije mnogo različito od obične manipulacije, konformizam nije neizostavno negativan fenomen.

Pozitivan konformizam primjetan je, naprimjer, u situacijama kada je on sve što je potrebno ljudima da bi preživjeli. Ne samo da zadovoljava potrebu čovjeka za blizinom drugog, nego i osigurava brzo prilagođavanje novim životnim zahtjevima i pravilima, što dalje utječe na stepen prihvaćenosti i doživljaj sigurnosti. U zapadnim kulturama, važnost konformiranja je naglašena, kao i insistiranje na društvu čvrstih individualista, pojedinaca koji misle samostalno i plivaju protiv struje za ono što smatraju ispravnim (Aronson, Wilson i Akert, 2005). S druge strane, istočne kulture i tradicionalne društvene zajednice vrednuju konformizam kao pozitivnu crtu jer omogućava očuvanje tradicionalnih vrijednosti društva. Ovo može biti jedan od razloga zbog čega se konformizmu u našem društvu pristupa nešto drugačije u odnosu na ranije navedene zapadnjačke kulture.

$\mathrm{Na}$ našim prostorima, konformizam se ponavljano ispituje kao vrijednosna orijentacija, dok objavljenih radova o izvršenim eksperimentima, iako su rađeni, nema mnogo dostupnih. Prema Petroviću, konformistička orijentacija je spremnost da se mišljenje većine nekritički prihvati, da se što bolje uklopi u postojeći društveni okvir, prilagodi drugima i odustane od sopstvene posebnosti. 
Među prvima treba spomenuti istraživanje koje su izvršili Hošek i saradnici na uzorku od 756 muškaraca starosti između 19 i 27 godina s teritorije, sada već bivše, SFRJ. Ovdje je konformizam posmatran kao jedan u nizu ispitivanih stavova pomoću pet skala Jerbića i Lukića (Hošek et al, 1989). Istraživanje Hošekove i njenih kolega rezultiralo je nalazima da postoji tendencija odsustva konformizma i to posebno kod ispitanika koji dolaze iz porodica s natprosječnim socijalnim statusom. Podaci iz 1989. godine sigurno nisu pomogli u predviđanju kolapsa jednog društva i vremena, a koji je uslijedio tek nekoliko godina kasnije, a što govori u prilog pretpostavci da stav prema nečemu ne mora nužno biti povezan s ispoljenim ponašanjem (La Pierre, 1934).

Kod nas se, vidimo, konformizam istraživao tek u rijetkim radovima i to od strane autora koji su obično koristili petostepene skale za ispitivanje konformizma kao vrijednosne orijentacije (Šram, 2008; Vučković i Gadžić, 2009; Koledin, 2011), dok o izvođenju eksperimenata ne postoji mnogo podataka na našim prostorima.

Šram (2008) u istraživanju na uzorku zagrebačkih studenata ispituje konformizam kao jednu od autoritarnih tendencija, dobivši rezultate da konformizam jeste značajan prediktor etnocentrizma i u pozitivnoj je korelaciji s autoritarnom poslušnosti, ali da međuodnosi konformizma i drugih varijabli nisu nužno jednoznačni u društvima različitih kulturnih naslijeđa i političkog konteksta.

Na Fakultetu za fizičko obrazovanje i sport u Banjoj Luci (Vučković i Gadžić, 2009) modifikovanu skalu konformizma Mehrabiana i Stefla (1995, prema Vučković i Gadžić, 2009) koristili su na uzorku od 75 košarkaša, a za ispitivanje konformizma kao oblika ponašanja igrača prema treneru i upravi kluba. Dobiveni rezultati pokazali su sklonost ka konformiranju i to u velikoj mjeri.

S druge strane, Koledin (2011) je ispitivala da li će spremnost da iznesu sopstveno mišljenje više pokazati studenti javnih ili studenti privatnih fakulteta. Dobivene značajne razlike potvrdile su polaznu hipotezu da su studenti privatnih fakulteta manje skloni konformističkom ponašanju, a više individualizmu i kritičkom mišljenju.

Među novijim radovima je značajno spomenuti i istraživanje urađeno na Filozofskom fakultetu Sveučilišta u Osijeku, R. Hrvatska (Jurkić, 2014), gdje je ispitivan odnos konformizma, taštine, samosvijesti i 
usmjerenosti na informacije o socijalnom upoređivanju kod različitih grupa kupaca. Za ispitivanje konformizma ovdje je korištena Kahleova skala motivacije za konformizam, koju je autorica primjenila na 400 ispitanika, ne dobivši pritom značajne spolne razlike te istaknuvši taštinu i usmjerenost na informacije o socijalnom upoređivanju kao prediktore konformizma. Iako empirijski rad, ovo istraživanje ipak ne zadovoljava uslove eksperimenta i ne može se smatrati replikacijom Aschovog rada. Zapravo, može se reći da je Aschov eksperiment jedan od rijetko ponavljanih, što je iznenađujuće ako se uzme u obzir da je njegov rad - jedan od temelja socijalne psihologije.

\section{Zaključak}

Romano vivito more.

(Kad si u Rimu, ponašaj se kao Rimljanin, latinska izreka)

Ljudi se konformiraju. Kao razloge zbog čega dolazi do konformizma u određenoj situaciji, može se izdvojiti više ključnih faktora kao što su privlačnost grupe za pojedinca (Festinger, 1954), nedostatak ili nisko samopoštovanja (Stang, 1972), brojnost grupe (Asch, 1956), potkrepljenje poslušnosti (Endler, 1966), važnost samog zadatka (Baron et al, 1996) te potkrepljivanje konformističkog ponašanja. Iako nijedan faktor nije jedini potreban uslov za nastanak konformizma, svaki od njih u nekoj mjeri daje objašnjenje ove pojave.

Istraživanja različitih autora potvrđuju kako je konformističko ponašanje značajan oblik socijalnog ponašanja. Međutim, ovakvo socijalno ponašanje široj nestručnoj publici nije zanimljivo, za razliku od nekih drugih socijalnih fenomena, koji su vjerno prikazani $u$ filmovima i knjigama. Jedno od rijetkih filmskih ostvarenja na ovu temu jeste "Konformist", igrani film iz 1970. godine, a u literaturi je Joneskov "Nosorog" iz davne 1959. najpoznatiji prikaz konformizma. Možda je upravo ovakav odnos društva prema konformizmu pokazatelj koliko je konformizam općeprihvaćena, svakodnevna pojava, prirodno stanje većine kojem se nema potrebe kritički pristupiti.

Socijalni utjecaj je, ipak, svakodnevna sastavnica funkcionisanja nekog društva. Biti dio cjeline ili biti cjelina, dilema je koja predstavlja važan unutrašnji konflikt, jer svaki čovjek želi biti nezavisan, ali istovremeno i dio zajednice. Moscovici (1976) ističe kako su Aschova istraživanja 
jedna od najdramatičnijih ilustracija konformizma, slijepog priklanjanja grupi, čak i kada pojedinac shvata da takvim postupanjem okreće leđa stvarnosti $\mathrm{i}$ istini. Utjecaj većine je toliko rasprostranjena $\mathrm{i}$ sveprisutna pojava da je pojam socijalnog utjecaja u grupama dugo predstavljao sinonim za konformizam. Postajanje članom grupe nije samo jedan od primarnih razvojnih zadataka tokom adolescencije - ova potreba javlja se mnogo ranije, ali se nastavlja i tokom odraslog doba pa i čitavog života. Premda je socijalni utjecaj najznačajniji za razvoj jedinke u tranzitnom i burnom adolescentskom dobu, nije zanemariv utjecaj koji socijalna sredina svakodnevno ima na pojedinca. Konformističko priklanjanje većini ili tzv. "mentalitet stada" svoje korijene ima i u urođenem afilijativnom motivu čovjeka, odnosno prirodnoj potrebi da se udružuje s drugima kako bi zaštitio samoga sebe i dobio mogućnost napretka, zaštićen kao ravnopravan član neke snažne grupe. Ljudi teže da budu prihvaćeni, čak i ako to znači da prihvataju stavove, vrijednosti i ponašanja koja su u suprotnosti s njihovim sopstvenim uvjerenjima. One koji se ne konformišu s većinom, socijalna sredina može okarakterisati kao različite, problematične i devijantne pa samim tim i nepoželjne. Modni stilovi, sleng, izbori poput odredišta za odmor, škole i posla, životnog partnera, sve su to svakodnevne, životne situacije u kojima je pritisak od strane društva bitan faktor i često ljudi, vođeni poznatom dvizom "Šta će drugi reći", donose odluke koje će biti u skladu s očekivanjima i poznatim vrijednostima od strane tih drugih, odnosno većine, bilo da to rade zbog vlastite neinformisanosti ili zbog želje da budu prihvaćeni kao ravnopravni članovi neke, njima važne, grupe.

Pregled literature o istraživanjima konformizma kao fenomena kojim se bavi socijalna psihologija, dovodi do zaključka da dosljedan obrazac istraživanja konformizma u skladu s trenutnim socijalnim trendovima i dešavanjima - ne postoji. Socijalni psiholozi u brojnim varijacijama Aschovog, rada dosljedno dolaze do zaključka da konformiranje postoji, u svim društvima i u svim periodima razvoja čovječanstva. Konformiranje, kao način prilagođavanja pojedinca društvu, općeprisutna je socijalna pojava, ali i neizostavno objašnjenje zbog čega ljudi pristaju da budu sve ono što neko drugi od njih očekuje da budu. Ovaj rad nije imao samo za cilj da obuhvati replikacije prvobitnih istraživanja konformizma i da pokaže raznolikost situacija u kojima do konformiranja dolazi, već je i uvod u istraživanje pozitivnog 
konformizma, koje može biti odgovor na prijetnje koje čovječanstvu donosi negativno konformiranje, nekritičko mišljenje i "mentalitet stada" - savremeni trendovi i realnost današnjice. Poznavanjem determinanti konformizma, kako ličnih tako i situacionih i stavovskih, ne samo da će se omogućiti predviđanje konformizma nego i njegovo izazivanje. Situacije u kojima snaga grupe može doprinijeti općem dobru, olakšati i ubrzati rješavanje određenih, svakodnevnih, životnih problema, u konformističkoj orijentaciji članova društva mogu dobiti potrebno. Ovo je osnovni razlog zašto konformizam ne treba posmatrati tek kao "dijete svog vremena", nego karakteristike ovakvog odgovora pojedinca na izloženost utjecaju grupe upotrijebiti za poticanje pozitivnih, socijalno prihvatljivih i poželjnih oblika ponašanja, npr. prosocijalnih ponašanja, odnosno omogućiti da grupa povede pojedinca u smjeru kojim se on sam ne bi usudio da krene.

\section{Literatura}

1. Abrams, D. \& Hogg, M. A. (1990) Social identification, selfcategorization and social influence. European Review of Social Psychology, 1, 195-228.

2. Aronson, E., Wilson, T. D. \& Akert, R. M. (2005) Socijalna psihologija. Zagreb: Mate.

3. Asch, S. (1956) Studies of Independence and Conformity: A Minority of One Against a Unanimos Majority. Psychological Monographs: General and Applied, 70 (9), 1 - 70.

4. Baron, R. S., Vandello, J. A. \& Brunsman, B. (1996) The forgotten variable in conformity research: Impact of task importance on social influence. Journal of - Personality and Social Psychology, 71, 915927.

5. Bond, R. \& Smith, P. B. (1996) Culture and Conformity: A MetaAnalysis of Studies Using Asch's (1952b, 1956) Line Jugment Task. Psychological Bulletin, 119 (1), 111-137.

6. Carpenter, J. P. (2004) When in Rome:conformity and the provision of public goods. Journal of Socio-Economics, 33, 395-408.

7. Cialdini, R. B. \& Goldstein, N. J. (2004) Social influence: Compliance and conformity. Annual Review of Psychology, 55, 591-621.

8. Egebark, J. \& Ekstrom, M. (2011) Like What You Like or Like What others Like? Conformity and Peer Effect on Facebook. Stockholm: Research Institute of Industrial Economics. 
9. Endler, N. S. (1966) Conformity as a Function of Different Reinforcement Schedules. Journal of Personality and Social Psychology, 3, 175-180.

10. Haun, D. B. M. \& Tomasello, M. (2011) Conformity to Peer Pressure in Preschool Children. Child Development, 82 (6), 1759-1767.

11. Hewstone, M. i Stroebe, W. (2003) Socijalna psihologija. Jastrebarsko: Naklada Slap.

12. Hošek, A., Momirović, K. \& Prišlin, R. (1989) Relacije statusnih karakteristika i socijalnih stavova mladih. Revija za sociologiju, 20 (34), 427-435.

13. Jurkić, M. (2014) Odnos konformizma, taštine, samosvijesti i usmjerenosti na informacije o socijalnoj usporedbi kod različitih skupina kupaca (neobjavljen diplomski rad). Osijek: Filozofski fakultet.

14. Koledin, G. D. (2011) Konformizam i stavovi studenata prema kvalitetu visokog obrazovanja. Zbornik radova sa naučnog skupa "Nauka i politika". Pale: Filozofski fakultet.

15. LaPiere, R. T. (1934) Attitudes vs. Actions. Social Forces, 13, 230 237.

16. Marjanović, N. (1995) Konformističko ponašanje adolescenata u vršnjačkoj grupi. Psihologija, 1-2, 123-132.

17. Milgram, S. (1961) Nationality and conformity. Scientific American, 205, 45-57.

18. Moscovici, S. (1976) Social influence and social change. London: Academic Press.

19. Moscovici, S. \& Zavalloni, M. (1969) The group as a polarizer of attitudes. Journal of Personality and Social Psychology, 12, 125-135.

20. Pennington, D. C. (1997) Društveni utjecaj. U: Pennington, D. C. Osnove socijalne psihologije. Jastrebarsko: Naklada Slap. 10, 244.

21. Rot, N. (2003) Osnovi socijalne psihologije. Beograd: Zavod za udžbenike i nastavna sredstva.

22. Santor, D. A., Messervey, D. \& Kusumakar, V. (2000) Measuring Peer Pressure, Popularity, and Conformity in Adolescent Boys and Girls: Predicting School Performance, Sexual Attitudes, and Substance Abuse. Journal of Youth and Adolescence, 29 (2), 163-182.

23. Schachter, S. (1951) Deviation, Rejection, and communication. Journal of Abnormal and Social Psychology, 46, 190-208. 
24. Sherif, M. (1936) The Psychology of Social Norms. New York and London: Harper \& brothers publishers.

25. Stang, D. J. (1972) Conformity, ability, and self-esteem. Representative Research in Social Psychology, 3(2), 97-103.

26. Šram, Z. (2008) Etnocentrizam, autoritarne tendencije i religioznost: relacije na uzorku zagrebačkih studenata. Migracijske i etničke teme, 24 (1-2), 49-66.

27. Teunissen, H. A., Spijkerman, R., Prinstein, M. J., Cohen, G. L., Engels, R. C. M. E., Sholte, R. H. J. (2012) Adolescents' Conformity to Their Peers' Pro-Alcohol and Anti-Alcohol Norms: The Power of Popularity. Alcoholism: Clinical and Experimental Research, 36 (7), 1257- 1267.

28. Van Schaik, C. P. (2012) Animal Culture: Chimpanzee Conformity? Current Biology, 22 (10), 402-404.

29. Vučković, I., Gadžić, A. (2009) Senior basketball players conformity. Homo sporticus issue, 1, 39-42.

30. Yafai, A. F., Verrier, D., Reidy, L. (2014) Social conformity and autism spectrum disorder: a child-friendly take on a classic study. Autism, 18 (8), 1007-1013. 


\title{
OVERVIEW OF TODAY'S CONFORMITY RESEARCH: “WHEN IN ROME, DO AS THE ROMANS DO”
}

\author{
MA Dijana Sulejmanović, Islamic Faculty of Pedagogy \\ University of Bihać \\ E-mail: dijana.sulejmanovic@unbi.ba
}

Abstract

As a result of social influence, the phenomenon of conformity can occur in small groups, but also throughout society as an act of comparing attitudes, beliefs, and behavior with group norms. Although the very existence of society implies the existence of a degree of conformity in the form of yielding to the demands of the majority, following trends and common activities for the advancement of humanity, the phenomenon of conformity is of interest to the researcher, usually in cases where it entails an individual's deviation from his or her own values, attitudes, opinions, and judgments most, either because he or she is unsure of the correctness of his or her assessment or does not want to compromise his or her position in a particular social group.

There is no general accepted explanation for conformity. Some authors define it as any adoption of group norms and others as changing behavior due to the group's imagined or actual pressure. But do individuals change their thinking under the influence of the social environment, or do they abandon their views only from the outside while privately maintaining their beliefs? What the shortcomings of past research on conformity are and how conformist has been examined in our region and in the world is a problem we deal with in this paper. The aim of the paper is to present the history and development of conformity research, from the pioneering work of Sherif and Asch to the present, while monitoring the results obtained and placing them in a historical and social framework.

Keywords: conformism, social influence, normative social influence, informational social influence. 


$$
\begin{aligned}
& \text { الماجستير سيدة ديانة سليمانوفيتش } \\
& \text { جامعة بيهاتش } \\
& \text { كلية التربية الإسلامية }
\end{aligned}
$$

E-mail:dijana.sulejmanovic@unbi.ba

\section{عرض الدراسات السابقة لظاهرة الإمعية وموافقة الأكثرية:

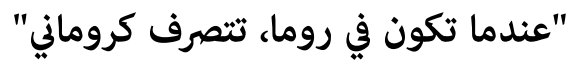

\section{| مللخص | (1)}

يمكن أن تحدث ظاهرة الإمعية وموافقة الأكثرية في مجموعات صغيرة، نتيجة للتأثير

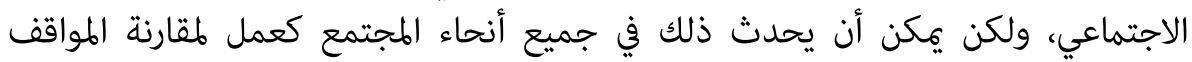

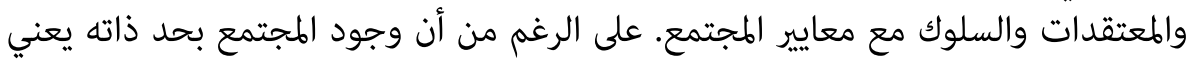

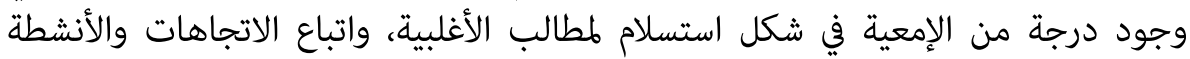

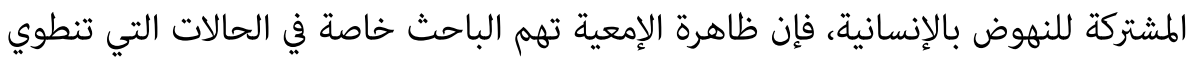

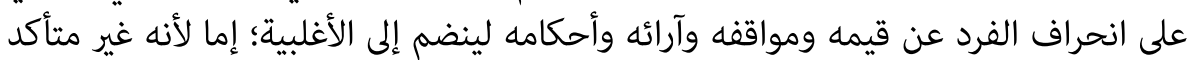

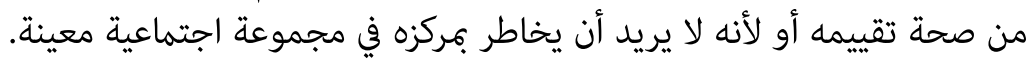

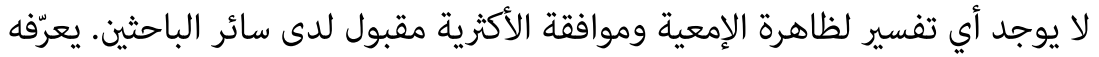

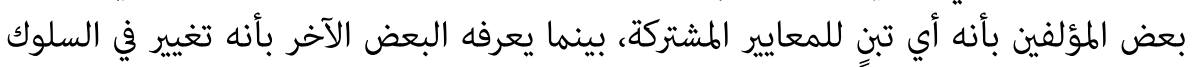

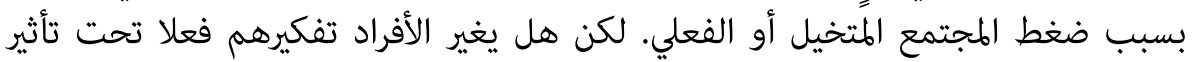

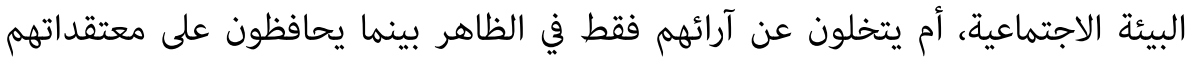

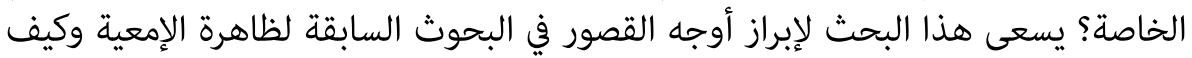
تمت دراسة هذه الظاهرة في منطقتنا وفي العالم.

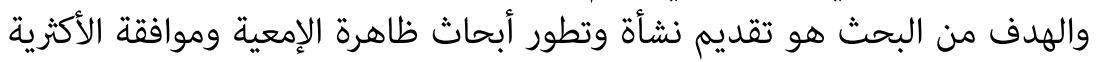

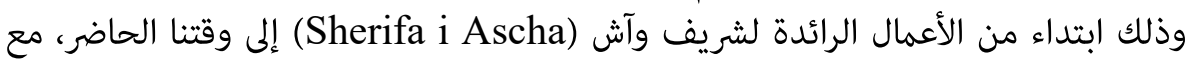

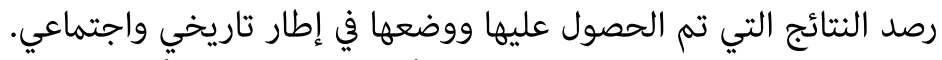

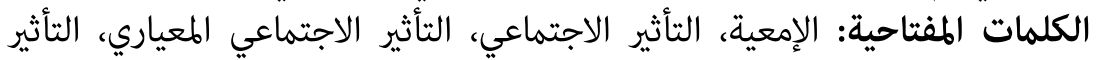

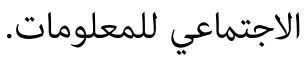

